\title{
Making the Countryside Global: The Bucharest School of Sociology and International Networks of Knowledge
}

\author{
Raluca Mușat* \\ History Faculty, Goldsmiths University of London, London SE14 6NW, UK \\ *ralumusat@yahoo.com
}

The interwar period was a time when the rural world gained new prominence in visions of modernity and modernisation across the world. The newly reconfigured countries of Eastern Europe played a key role in focusing attention on the countryside as an important area of state intervention. This coincided with a greater involvement of the social sciences in debates and in projects of development and modernisation, both nationally and internationally. This article examines the contribution of the Bucharest School of Sociology to the creation of an idea of 'the global countryside' that emerged in the interwar years and only matured in the post-war period.

Dear Mr. Golopenția, I received your letter via Mr. Cressin and I was really pleased as, since the end of the war, I have been trying to get news from you at every occasion, as few and uncertain as these were. ... I am also glad that you thought of sending me some materials, too, and please do keep me posted about any studies about social matters and about state organisation by us, whenever you can. ... What studies are happening over there? Does the Institute still exist? What became of the collaborators I've met? . . . If it is possible, I'd be happy to hear news about those I worked with in the past and I hope you will write to me a bit more about your activities. ${ }^{1}$

This letter from the British social historian David Mitrany (1888-1975) to the Romanian sociologist Anton Golopenția (1909-50) was part of a larger set of correspondence intended to retie the academic and social relations between Eastern and Western academia at the end of the Second World War. ${ }^{2}$

Golopenția was a prominent member of the Bucharest School of Sociology, whose field trips to the countryside he first joined in 1931. The School, established in the mid 1920s by the professor of sociology Dimitrie Gusti (1880-1955), was one of the most important research communities dealing with rural matters in interwar Europe. It pioneered field trips to the countryside and later launched several projects aimed at reforming life in rural Romania. ${ }^{3}$ As part of this group Golopenția pursued an academic career as a rural sociologist. In the late 1930s he led several important research projects on the peasantry that gained international recognition. ${ }^{4}$ Alongside his research, Golopenția worked for the newly established Central Institute of

\footnotetext{
1 David Mitrany, 'Scrisoare David Mitrany - Anton Golopenția (3.5.1946)', in Anton Golopenția, Ultima Carte. Text integral al declarațiilor în anchetă ale lui Anton Golopenția aflate în Arhivele S.R.I. (Bucharest: Ed. Enciclopedică, 2001), 354.

2 Golopenția, Ultima Carte, 351-448.

3 Zoltán Rostás, Atelierul gustian (Bucharest: Ed.Tritonic, 2005); Antonio Momoc, Capcanele politice ale sociologiei interbelice. Școala gustiană între carlism și legionarism (Bucharest: Curtea Veche, 2012).
} 
Statistics in Bucharest. After the war he remained with the Institute despite refusing to join the Communist Party. In 1948, when sociology was erased from the academic curriculum and sociologists were dismissed from their academic and public positions, Golopenția lost his job. He was subsequently incarcerated in 1950 and died in prison after eighteen months of detention. ${ }^{5}$

Golopenția's correspondence shows the close academic links between East and West that continued in the immediate post-war period, while his tragic fate symbolises the sudden end to these relations and the general amnesia that descended over this episode in the history of the social sciences. Despite the lively academic exchange between the newly defined region of Eastern Europe and the West in the interwar years, the break in these relations, which happened in the post-war period, has shaped the history of the social sciences ever since, keeping it as an almost exclusively Western story. ${ }^{6}$

This article uses the academic networks and intellectual connections between Eastern Europe and the West to re-examine the origins of a global way of conceptualising the rural world and its modernisation in the interwar and post-war periods. The interwar period saw a re-emergence and an internationalisation of the interest in the rural world, while in the post-war period this interest fed into debates about the 'development' of non-Western societies. Eastern European scholars played a special role in the internationalisation and eventual globalisation of rural debates. The article shows how the study of rural life made its way from discreet local initiatives to worldwide projects and discussions.

Looking at intellectual networks of knowledge offers the advantage of an embodied approach in which individuals and objects are connected through real exchanges and interactions or transactions. ${ }^{7}$ These exchanges contributed to a vision of 'a global countryside' that emerged as part of the development paradigm after the war. This represented a way of seeing the countryside as a borderless geographic (and cultural) continuum with common problems and with potentially common solutions that needed to be solved in spite of the great diversity inherent to peasant living. ${ }^{8}$ The term 'global countryside' is therefore used somewhat anachronistically in this article, as it was not part of interwar debates. It also differs from that employed to describe the effects of contemporary globalisation on the life of rural dwellers and their economic activities. 9

\section{A Shifting Vision of the Rural World}

After the First World War the romantic and nostalgic view of the rural world was balanced or even superseded by a harsher realism that saw it as a place wrought with 'dirt, backwardness, ignorance and superstition' in need of improvement and intervention. ${ }^{10}$ This was in part due to

\footnotetext{
4 Anton Golopenția and Dan Corneliu Georgescu, 60 de sate românești cercetate de echipele studentești în vara 1938: Anchetă sociologică condusă de Anton Golopenția și dr. D. C. Georgescu (Bucharest: Institutul de Științe Sociale al României, 1941); Anton Golopenția and Mihai Pop, Dâmbovnicul: o plasă din sudul Județului Argeș : câteva rezultate ale unei cercetări monografice întreprinse în 1939 (Bucharest: Institutul de Științe Sociale al României, 1942).

${ }^{5}$ Golopenția, Ultima carte.

6 The prestigious Cambridge History of Science volume dedicated to the social sciences deals with Western sociology separately and does not even mention it in the separate section dedicated to the internationalisation of the social sciences'. Theodor Porter and Dorothy Ross, eds., The Modern Social Sciences, The Cambridge History of Science, Vol. 7 (Cambridge: Cambridge University Press, 2003).

7 Rajeev K Goel, Devrim Göktepe-Hultén and Rati Ram, 'Academic Networks and the Diffusion of Knowledge', in Cristiano Antonelli and Albert N. Link, eds., Routledge Handbook of the Economics of Knowledge (Abingdon: Routledge, 2015), 79-98.

8 James C Scott, Seeing Like a State: How Certain Schemes to Improve the Human Condition Have Failed (New Haven: Yale University Press, 1998), 224.

9 Michael Woods, 'Engaging the Global Countryside: Globalization, Hybridity and the Reconstitution of Rural Place', Progress in Human Geography, 31, 4 (2007).

10 Iris Borowy, Coming to Terms with World Health (Frankfurt am Main: Peter Lang GmbH, 2009), 326.
} 
the changes that affected national and international politics as well as the rural world itself. The peasantry became closer to the states or empires they lived in and, in many parts of Europe, large areas of land were transferred from the upper classes to the peasant population. Almost all the new states in Eastern Europe were confronted with questions about modernising their largely agrarian societies. According to Ivan Berend, 'social and political emancipation of the peasantry ... . [had become] a tenet of modernisation policy' even before the war and grew significantly in importance afterwards. ${ }^{11}$ The impulse to modernise the countryside went hand in hand with the rise of nationalism across most of Europe, which brought along a glorification of the peasantry as a unique source for the potential renewal of the nation state. ${ }^{12}$ In Eastern Europe this made the peasantry into an important subject of politics, although not necessarily into an important political actor.

On an international level this new vision of the rural world was clearly visible in the disciplines of social health and hygiene which had shifted their attention from urban to rural settings. As Lion Murard noted, 'social medicine in Europe had begun to tilt away from urban settings. Not only did its welfare commitments appeal to the rural masses, but its particular, intensely communal, achievements drew the real map of European health care'. ${ }^{13}$ This coincided with a change of paradigm from a one-size-fits-all to a more localised approach. In this new context' Eastern Europe, the region with the largest proportion of peasant population on the continent, became a site for small-scale experimental projects aimed at the prevention and treatment of rural diseases and at the general improvement of living conditions in the countryside. These attracted the support of the Rockefeller Foundation and the League of Nations Health Organisation (LNHO), who helped create a vision of the countryside as a global space with shared problems and solutions. ${ }^{14}$

Similarly, ideas of rural economic development were also on the rise in this period. These originated in areas with a high proportion of the population living in rural areas, such as Russia, Eastern Europe and Latin America, where solutions for catching up with the West were investigated. ${ }^{15}$ In Eastern Europe the new situation at the end of the war allowed specialists to pioneer their ideas within projects of state building at home and, at the same time, to initiate or join wider conversations within international forums. Eastern European scholars therefore played a major part in making the countryside a target for national and international intervention. The interest in the rural world was not confined to the academic world alone but became highly political, cutting across disciplinary boundaries and the academic and political spheres. The social sciences played a key role in the 'governing of the rural' by becoming both more empirical and by strengthening their applicability to projects of social reform. ${ }^{16}$ Politicisation also defined the social sciences in this period and allowed them to thrive.

Gusti's School of Sociology illustrated this phenomenon. Gusti played an active role in raising the status of the social sciences in his country by setting up several important institutes and forums for scholarly and political debate and by initiating several projects of rural reform. ${ }^{17}$ The Romanian Social Institute (Institutul Social Român) and the Bucharest School of Sociology

11 I. T. Berend, Decades of Crisis: Central and Eastern Europe Before World War II (Berkeley: University of California Press, 2001), 288.

12 Jeremy Burchardt, 'Editorial: Rurality, Modernity and National Identity between the Wars', Rural History, 21, 2 (2010).

13 Lion Murard, 'Designs within Disorder: International Conferences on Rural Health Care and the Art of the Local, 19311939', in Susan Gross Solomon, Lion Murard and Patrick Zylberman, eds., Shifting Boundaries of Public Health. Europe in the Twentieth Century (Rochester, NY: University of Rochester Press, 2008), 145.

14 Murard, 'Designs'.

15 Joseph Love, Crafting the Third World: Theorizing Underdevelopement in Rumania and Brazil (Stanford, CA: Stanford University Press, 1996).

16 Kiran K Patel, 'Introduction', in Liesbeth van de Grift and Amalia Ribi Forclaz, eds., Governing the Rural in Interwar Europe (London: Routledge, 2017).

17 Dimitrie Gusti, 'Realitate, știință și reformă socială. Câteva indicații asupra metodei', Arhiva pentru știință și reformă socială, I, 1 (1919), XXV. 
became well known and attracted the attention and collaboration of foreign scholars from Europe and further afield. ${ }^{18}$ As an American contemporary pointed out, Romania dominated the region in terms of publications and institutions for sociological research. ${ }^{19}$ Over the period the School also became actively involved in international exhibitions and conferences discussing the fate of the rural world on a global scale, presenting their own theories and findings.

\section{Sociology and the Peasantry in Romania}

Debates about the rural world gained new importance in the aftermath of the First World War, when a significantly enlarged Romanian state emerged. ${ }^{20}$ The war mobilised the peasantry in the Old Kingdom and the Russian Revolution made the government fear the potential spread of protest amongst Romanian peasants, whereas the 1918 unification gave national importance to problems of the peasantry and its modernisation. Romania's territorial expansion meant the addition of several significant minority groups to a previously almost homogeneous population, making the peasantry, which constituted over 70 per cent of the population, the largest ethnic Romanian group. ${ }^{21}$ In the new regions ethnic minorities dominated the cities, while the majority of Romanians lived in the countryside. This meant that, despite the great diversity, this new peasant population came to be seen as greater Romania's national 'common denominator', becoming the target of many 'nationalizing' efforts. ${ }^{22}$

The major land redistribution of 1921 was the first step in the transformation of the peasantry across the old and new territories. The land reform broke up the large-scale latifundia and made most peasants owners of a small plot of land. A second step was represented by the new Romanian Constitution (1923), which gave all male peasants the right to vote. This in turn reshaped Romania's political scene, giving rise to political parties representing peasant interests such as the National Peasant Party, which competed with the established Liberal Party and held office for a limited period during the Great Depression (1928-31 and 1932-3). Finally, reforms of the education system during the 1920s sought to tackle the high illiteracy rates - especially amongst the rural population - by making primary education free and compulsory, increasing the number of village schools, training more teachers and giving more opportunities for peasant pupils to continue their education. ${ }^{23}$

Overall, although these reforms transformed life in the countryside in many ways, they did little to improve rural living conditions, to provide real political representation or to create an efficient peasant-based agriculture. Instead, during the interwar period peasants continued to face an array of specific problems including poverty, poor hygiene and living conditions, illness, high infant mortality and low literacy. ${ }^{24}$

Much of this situation was caused by the lack of real political solutions to improve Romanian agriculture. Instead, the emphasis of interwar economic policy remained on industrialisation, despite the great importance given to the peasantry in political discourse. Nevertheless, despite

18 Dietmar Müller, 'Instituționalizarea cunoaşterii științelor sociale în perioada interbelică: Institutul Social Român și Asociația de Politică Socială’, in Politici culturale și modele intelectuale în România (Cluj-Napoca: Mega, 2013); Rostás, Atelierul gustian.

19 Joseph S Roucek, 'Sociology in Roumania', American Sociological Review, 3, 1 (1938).

20 H. L. Roberts, Rumania: Political Problems of an Agrarian State (New Haven: Yale University Press, 1951); K. Hitchins, Rumania: 1866-1947 (Oxford: Oxford University Press, 1994).

21 Irina Livezeanu, Cultural Politics in Greater Romania: Regionalism, Nation Building and Ethnic Struggle, 1918-1930 (Ithaca, NY: Cornell University Press, 1995), 8-9.

22 Rogers Brubaker, Nationalism Reframed; Nationhood and the National Question in the New Europe (Cambridge: Cambridge University Press, 1996).

23 Livezeanu, Cultural Politics, 34-44.

24 Dimitrie Gusti, Nicolae Cornatzeanu and George Banu, Rural Life in Rumania. An Abridged English Version of a Monograph 'La Vie Rurale En Roumanie' (Bucharest: Fourth International Congress of Sociology, 1940); Anton Golopenția, 'Despre starea culturală și economică a populației rurale din România', Revista de igienă social, X, 1-6 (1940). 
the inadequacy of interwar rural politics, the scholarship on rural matters made great progress during this period. Social scientists, alongside representatives of other disciplines with direct application to social reform, shone a harsh light on Romania's new rural questions. Gusti, for example, seized every opportunity to establish sociology in the public sphere and to make it into a tool for modern governance. ${ }^{25}$

Gusti was trained in Germany, where he studied with some of the most prominent figures in the social sciences of the time: the economist Karl Bücher, cultural historian Karl Lamprecht and the experimental psychologist Wilhelm Wundt. ${ }^{26}$ He sought to develop a comprehensive system of thought that combined three main domains: sociology, ethics and politics. His system involved a natural progression from the objective understanding of 'social reality', realised through sociology, to its transformation in the realms of politics and, eventually, of ethics. In his view society was an entity above and beyond a sum of individuals that could be studied and understood scientifically. ${ }^{27}$ His core principle, inspired by Wundt's work, was that of 'social will', which was 'the nature of social life'. This represented 'a system of goals' which 'gave sense to social phenomena' and enabled them to become manifest. Comparable to Durkheim's 'conscience collective', Gusti's concept of 'social will' represented 'the existential and functional mechanism of society as such'. ${ }^{28}$ Each social unit responded with its own form of social will to its pre-determining factors, which Gusti defined as 'contexts' (cadre), thus producing its unique social activity or, as he defined it, its unique 'manifestations' (manifestări). This resulted in a process of 'social parallelism', summed up in the formula $C$ (contexts) $+V$ (social will) $=M$ (manifestations). This meant that each social unit, determined by its specific conditions and guided by its social will, produced its own manifest social reality. ${ }^{29}$ Social reform therefore represented the calibration of the social will of a social group.

Like many members of his generation Gusti was not only a scholarly figure but also a reputable member of the intellectual and political elite in Romania, occupying many public posts. ${ }^{30}$ These positions gave him access to political leaders, to national funding and to networks abroad, allowing him to popularise his discipline and the method of field research both at home and abroad.

The Bucharest School of Sociology was born in the mid 1920s out of Gusti's initiative to supplement his seminars with annual summer expeditions to different Romanian villages, where students and other scholars could study peasant life. ${ }^{31}$ The School developed their unique style of 'monographic sociology' that applied Gusti's social theory to the study of Romanian villages. This new kind of sociological research was meant to bring together two main directions of study that had developed separately: theoretical sociology and the social survey tradition. The monographic method drew on and sought to supersede an established tradition of gathering first-hand information about different social groups that included Frédéric Le Play's (1806-82) monographs and those of his followers, different schools of statistical research, the Romanian nineteenth century questionnaire based method of collecting information about the peasantry and con-

\footnotetext{
25 Gusti, 'Realitate', XXV.

26 Ovidiu Bădina, 'Studiu introductiv', in Dimitrie Gusti - Opere, Vol. I (Bucharest: Editura Academiei Republicii Socialiste Romania, 1968), 5-200.

27 Dimitrie Gusti, La Science de la réalité sociale (Paris: Alcan. Presses universitaires de France, 1941).

28 Traian Herseni, 'Teoria monografiei sociologice', in Dimitrie Gusti, Traian Herseni and Henri H. Stahl, Monografia teorie și metodă (Bucharest: Paideia, 1931), 83.

29 Gusti, La science.

30 During the 1920s, Gusti was president of Casa Autonomă a Monopolurilor (The State Monopolies Commission), president of Societatea Română de Radiodifuziune (The Romanian Broadcasting Service) and of the Oficiul Național de Cooperație (The National Cooperative Bureau). In 1932 he was briefly appointed Minister of Education under the Peasant Party government, a position he had to leave after only a year.

31 Rostás, Atelierul gustian; Zoltán Rostás, Sala luminoasă. Primii monografiști ai Școlii Gustiene (Bucharest: Paideia, 2003).
} 
temporary trends in US rural sociology. ${ }^{32}$ The innovation of the Bucharest School came from the marriage between a complex theoretical system and a method of study that 'gathered its own materials' and thus generated new, unique and appropriate sources for sociological research. ${ }^{33}$ According to their view each village would be examined according to the main determining 'contexts' of its social phenomena (cosmological, biological, historical and psychological), their main 'manifestations' (spiritual, economic, political-administrative and cultural) and social units, relations and processes. ${ }^{34}$

Gusti's 'monographic trips' attracted students and scholars from different backgrounds, who created a real intellectual hub focused on the empirical study of rural issues. In the mid to late 1920 s the School gathered a substantial amount of material from villages from both the old and the new territories. By the mid 1930s the School's main representatives started formulating coherent ideas about Romania's 'rural problems' and their potential solutions. The large-scale research campaigns of the late 1930s offered a complex and in-depth view of the condition of life in the countryside both in discreet regions (Nerej, Vrancea) as well as across a much larger territory (60 de sate). ${ }^{35}$ The main problems highlighted, amongst others, were: the 'crisis of traditional life' caused by a rapid adoption of modern ways of life, the demographic problem of overpopulation and its economic effects on the peasantry, the low standard of living in the countryside caused by poor agricultural techniques and land fragmentation and pressure on the land. In answer to these problems, Golopenția, for example, proposed political solutions that involved heavy state intervention and planning. ${ }^{36}$

Monographic sociology was from the beginning connected to the idea of social reform. First of all, Gusti's whole sociological system posited a necessary link between ethics, politics and sociology. Secondly, his main initiatives in the 1920s were meant to produce knowledge about Romania's social reality that could be used to inform governance. Thirdly, the evolution of Romanian politics also gave Gusti the opportunity to use sociology as a direct tool for social reform. In mid to late 1930s Gusti and part of the School initiated several projects of rural reform, which were funded directly by the country's new monarch, King Carol II. ${ }^{37}$ The new king, who came to the throne in 1930 after initially renouncing it, was especially interested in rural culture and modernisation. His vision of rural reform matched, at least superficially, Gusti's, combining a desire to preserve cultural traditions with one of improving the general state of life in the countryside. Moreover, the king was also interested in gaining the support of young people and of peasants, who were at the time being recruited heavily into the fascist Legion of the Archangel Michael (Legiunea Arhanghelului Mihai). ${ }^{38}$

In 1934 the king placed Gusti in charge of the 'Prince Carol' Royal Cultural Foundation, an institution the former had set up for the enlightenment of the peasantry. ${ }^{39}$ The project of 'cultural work' (muncă culturală), launched in 1934, sought to mobilise all professions seen as vital to the improvement of peasant life (human and veterinary medicine, agronomy, physical education, domestic science and theology) under the umbrella of sociology in an effort to

32 Dimitrie Gusti, 'Sociologia monografică. Știință a realității sociale’, in Gusti et al. Monografia, 5-75.

33 Traian Herseni, 'Metoda monografică în sociologie', Societatea de mâine, VI, 16-17 (1929), 250-1.

34 Henri H. Stahl, 'Tehnica monografiei sociologice', in Gusti et al. Monografia (Bucharest: Paideia, 1999), $175-387$.

35 Henri H. Stahl, Nerej, un village d'une région archaïque (Institut de Sciences Sociales Roumaines, 1939); Anton Golopenția and Dan Corneliu Georgescu, 60 de sate românesti cercetate de echipele studentești în vara 1938: Anchetă sociologică condusă de Anton Golopenția și Dr. D. C. Georgescu (Bucharest: Institutul de Științe Sociale al României, 1941).

36 Golopenția, 'Despre starea culturală'.

37 On King Carol II, see Ion Scurtu, Istoria românilor În timpul celor trei regi. Carol Al II-Lea (Bucharest: Ed. Enciclopedică, 2010); Paul Quinlan, The Playboy King: Carol II of Romania (Westport, CT: Greenwood, 1995).

38 Of the many historical accounts of the LAM, see Armin Heinen, Legiunea 'Arhanghelul Mihai' (Bucharest: Humanitas, 2006); Roland Clark, Holy Legionary Youth (Ithaca, NY: Cornell University Press, 2015).

39 Zoltán Rostás, 'Fundația Culturală Regală "Principele Carol” sau mișcarea echipelor studențești voluntare', in Strada Latină Nr.8. Monografiști și echipieri la Fundația Culturală Regală "Principele Carol” (Bucharest: Curtea Veche, 2009), $11-23$. 
modernise the rural world. Between 1934 and 1938 hundreds of university students and graduates, from a wide variety of disciplines, were recruited and sent to the countryside to study peasant life and help improve it. ${ }^{40}$ In 1938, the first year of the royal dictatorship, Gusti launched the Social Service (Serviciul Social), a programme of work experience in the countryside compulsory for all university students, graduates and civil servants. ${ }^{41}$ Although short lived, the Social Service made the reorganisation of the countryside a state priority. ${ }^{42}$

These applied projects implicated sociology into the political turmoil of the time, creating internal seizures and placing it in a complicated relationship both with fascism, represented by the Legion, and with Carol's authoritarianism. Internally, Gusti's ambition to apply sociology to rural reform created a split within the School, between those like Vulcănescu and Herseni, who saw this as a deviation from theory and a perversion of science, and those like Stahl and Golopenția, who joined Gusti at the Royal Foundation. Externally, Gusti's projects, which were funded by the king, competed with the Legion's own voluntary work in the countryside, seeking to offer both students and peasants an alternative to the fascist camps. ${ }^{43}$ However, the alternative to fascism was merely that of authoritarianism, which allowed Gusti to launch the more ambitious Social Service project. ${ }^{44}$

By applying sociology to rural reform Gusti turned the discipline into a tool of authoritarian politics. In this vision social experts and educated young people would help connect the countryside to the state by leading a civilising mission that, alongside its desired modernising goals, would also provide allegiance to the country's authoritarian ruler. The desired aim was to create a new form of social cohesion - between the rural and the urban and across generational divides. This vision of rural modernisation, which combined a preservation of tradition with rational improvements to peasant life, was far from unique to Romania. A similar marriage between scientific expertise and (mostly) non-democratic politics was to be found in many other European and non-European states, such as fascist Germany and Italy as well as Kemalist Turkey. ${ }^{45}$ The politics of rural reform and governance therefore indicate that whilst interwar ideas about the countryside were going global, the contexts in which they were produced and their applicability remained within the limits of national and nationalist visions of modernisation. ${ }^{46}$

\section{The East: Intellectual Formation}

For the leading members of the Bucharest School of Sociology, their academic training, both at home and abroad, made them see the international value of their research into the Romanian countryside. After the end of the First World War there was a gradual growth of student intake and widening participation in Romanian higher education. This led to fewer students choosing to study abroad for their first degree, although many were interested in undertaking advanced studies after completing one or two degrees in Romania. ${ }^{47}$ The avenues and opportunities for

40 Raluca Mușat, “"To Cure, Uplift and Ennoble the Village”: Militant Sociology in the Romanian Countryside, 1934-1938', East-European Politics and Societies, 27, 3 (2013).

41 The royal dictatorship, announced in February 1938, marked the shift from a constitutional to an authoritarian regime; the King dissolved the parliament and the 1923 constitution, instituting his new 'government above the parties' and a new corporatist Constitution. Keith Hitchins, Rumania: 1866-1947 (Oxford: Clarendon Press, 1994), 430-2.

42 Dimitrie Gusti, Principiile și scopurile Serviciului Social (Bucharest: Fundația Culturală Regală 'Principele Carol', 1939).

43 Rebecca Haynes, "Work Camps, Commerce, and the Education of the "New Man" in the Romanian Legionary Movement', Historical Journal, 51, 4 (2008).

44 Dimitrie Gusti, 'Serviciul Social obligatoriu', in Dimitrie Gusti, Opere.III.Politica, n.d., 327-33.

45 Raluca Mușat, 'Lessons For Modern Living: Planned Rural Communities in Interwar Romania, Turkey and Italy', Journal of Modern European History, 13, 4 (2015).

46 Liesbeth Van de Grift and Amalia Forclaz, eds., Governing the Rural in Interwar Europe (London: Routledge, 2017).

47 Irina Nastasă Matei, 'Studenții români în perioada interbelică, între educația "națională” și universitățile occidentale', in Lucian Nastasă and Dragoș Zdrobiș, eds., Politici culturale și modele intelectuale în România (Cluj-Napoca: Mega, 2013), $210-27$. 
foreign study in this period varied, with funding from domestic institutions, government-funding schemes and newly established exchange programmes.

This generational divide was visible within the Bucharest School of Sociology. Unlike the generation of scholars born at the end of the nineteenth century, represented by Gusti himself, who conducted most of their university studies abroad, those born in the first decade of the twentieth century were mostly trained at home but had access to study in foreign institutions for shorter periods or at postgraduate level.

Golopenția's academic career path illustrated the common route for students of his generation: a first degree in Romania, followed by advanced studies abroad. ${ }^{48}$ He completed two degrees at the University of Bucharest, one in Law and one in Philosophy and Letters. After a brief appointment as Gusti's private secretary at the Ministry of Education, he left to pursue his doctoral studies in Germany with the help of a Rockefeller Foundation bursary. In a questionnaire completed in 1930 he answered the question 'Do you think it is necessary to continue your studies abroad?' by saying that Romanians needed to understand 'what the 'MediterraneanChristian-European culture and civilisation' had produced in order to assimilate and overtake it. He also criticised the students who chose to study abroad too early:

For study abroad to be useful to Romania, [students] should not leave until after their degree at the earliest. Those who leave Romania with no orientation, not properly rooted in its way of thinking, can easily become estranged from it when they come into close contact with an imposing culture and civilisation. They often therefore end up despising or at least deploring the situation at home. This is most likely to happen out of ignorance. ${ }^{49}$

This statement explained a feeling shared by the School that a national horizon was crucial to making the connection to the international scene.

Golopenția's career reinforced this direction. After his doctoral studies in Berlin and Leipzig, where he worked with professors Hans Freyer and Arnold Gehlen, he returned to sociological endeavours in the countryside with new ideas that he applied in the collective research of sixty Romanian villages he led in $1938 .^{50}$ These included a combination of statistical (quantitative) and monographic (qualitative) methods meant to produce a comprehensive view of the main problems of the Romanian countryside. Also, Golopenția's studies in Nazi Germany reinforced his opinion that the social sciences should become tools for state intervention and social reform. Whilst working with students whose views ranged from right-wing to communist, Golopenția seemed to think that the models to be followed where those of countries like Germany and Italy, where activism and state intervention were being implemented at high speed. ${ }^{51}$

Traian Herseni (1907-80), one of the School's main theorists, followed a similar academic career to Golopenția. He graduated from the Faculty of Letters at the University of Bucharest and went on to specialise in sociology at the University of Berlin, where he studied with Werner Sombart, Alfred Vierkandt and Eduard Spranger. ${ }^{52}$ Herseni worked on defining a position for Romanian sociology on a wider international stage, promoting its unique features and highlighting its potential. ${ }^{53} \mathrm{He}$ argued that Romanian sociologists could no longer merely follow foreign schools and trends. Unlike other Western sociological traditions, the Romanian discipline

\footnotetext{
48 Anton Golopenția, Anton Golopenția. Opere complete. Sociologie, Vol. I (Bucharest: Ed. Enciclopedică, 2002).

49 Ibid., 53.

50 Golopenția and Georgescu, 60 Sate.

51 Federico Caprotti, Mussolini's Cities: Internal Colonialism in Italy, 1930-1939 (New Jersey: Cambria Press, 2007); Victoria De Grazia, The Politics of Leisure: The Dopolavoro and the Organization of Workers' Spare Time in Fascist Italy, 19221939 (Cambridge: Cambridge University Press, 1981); Jurgen Schiedeck and Martin Stahlmann, 'Totalizing of Experience: Educational Camps', in Heinz Sünker and Hans-Uwe Otto, eds., Education and Fascism: Political Identity and Social Education in Nazi Germany (London: Routledge, 1997).

52 Marin Diaconu, 'Traian Herseni - Centenarul nașterii', Revista română de sociologie. Serie nouă, XVIII, 1-2 (2007).

53 Traian Herseni, 'Metoda monografică în sociologie', Societatea de mâine, VI, 16-17 (1929), 250-1.
} 
had to develop its unique strength by creating a 'sociology of peasant civilisation'. ${ }^{4}$ This would make Romanian culture truly international not by transcending the nation but by affirming it on the world stage.

Whilst Herseni's work was based on a thorough understanding of both classical and contemporary Western social theory, his aim was to find or fashion the best tools to understand Romanian social reality, especially in a rural context. In this sense their international connections worked to strengthen their national aspirations but also to give Romania's peasant problems an international dimension that could, in turn, widen the subject matter of sociology as a discipline more generally.

The academic training showed a desire to make the study of Romanian rural life internationally relevant. Learning about their own countryside allowed Romanian sociologists to contribute to international debates about rural modernisation and to attract the attention of foreign scholars. In this respect the national dimension was the way to develop the international one, a relationship that should be seen as complimentary rather than in opposition.

\section{The West: Travelling East}

Academic mobility in the interwar period was not one directional but also involved Western scholars going East. After the First World War Eastern Europe became a place of interest for international organisations and for individual Western scholars. In the West, new institutions like the School of Slavonic and East European Studies in London were set up to study the region and its specificities. The range of social, economic and political issues posed by the region also became of interest to the Carnegie and Rockefeller foundations, who funded scholars to travel to the region and study its features.

Most of the social scientists that travelled to Romania in this period came in contact with Gusti and his School. Gusti was well known and often recommended as a first point of contact, especially for scholars interested in the countryside. All three scholars discussed below (David Mitrany, Doreen Warriner and Philip Mosely) met with members of the School, joined them on their trips and became acquainted with their work. For all of them, this offered access to the Romanian countryside and contributed to forging their vision of the region and of rural issues. Despite their different agendas all three highlighted the importance peasant issues gained in this period both within the region and outside of it. They all helped shape a vision of the global countryside after the war. Furthermore, their post-war career paths show the way in which local and regional concerns became international after the war.

Of the three, Mitrany, a British sociologist and journalist of Romanian origins, was one of the first scholars of the region to cast a light on the return of peasant matters to the forefront of European political, social and economic debates. ${ }^{55}$ His career path also illustrated the increasing interest in social matters pioneered by the US foundations. Mitrany initially worked as the assistant European editor of a series of publications dealing with the 'economic and social history of the war', sponsored by the Carnegie Endowment for International Peace. ${ }^{56}$ After accompanying John Shotwell, the editor of the series, on a visit to Romania in 1925, he accepted the commission to write one of the volumes in this series, focusing on Romania. The book, The Land and the Peasant in Rumania: The War and Agrarian Reform (1917-21), was a study of the postFirst World War land reforms. It indicated that the peasant problems of Eastern Europe, in this case Romania, represented more than just local issues and were instead seen as part of a general history of the First World War and of its social and economic consequences for Europe, East and

\footnotetext{
54 Traian Herseni, 'Sociologia românească', Societatea de mâine, VII, 11 (1930), 217-8.

55 Dorothy Anderson, 'David Mitrany (1888-1975): An Appreciation of His Life and Work', Review of International Studies, 24 (1998), 578.

56 Ibid.
} 
West. Mitrany had met Gusti at the Romanian Social Institute on his first visit with Shotwell. ${ }^{57}$ He was also aware of the sociological studies produced in Romania under Gusti's supervision and guidance.

After his initial work on land reforms Mitrany went on to write about the unique problems posed by the peasant question both for the politics of interwar Europe and for the wider sociology of modernisation more generally. His later book, Marx against the Peasant: A Study in Social Dogmatism, challenged scholars to revisit the problem that the peasantry and its interwar revival posed to Marxist theory, also offering a comprehensive study of the 'green rising', the rise of Peasant Parties and movements as an interwar political phenomenon. ${ }^{5}$

During and after the Second World War Mitrany pursued a career in the growing field of international relations, becoming known as one of the main proponents of functionalism, a theory that emphasised the benefits of international cooperation and integration on different levels as opposed to the pursuit of purely nationalist agendas. This new direction grew out of his work and understanding of the fallacies of interwar politics, of which nationalism was a major one. ${ }^{59}$ Mitrany's career and academic interests therefore reflected the rising interest in the peasant issues of Eastern Europe as a matter of international concern. He argued that the problems posed by the peasantries of Eastern Europe were not local or regional petty matters but important manifestations of yet unresolved problems of modernisation. They were by no means unique to the region but would reappear in a different and much more widespread form after the war in many non-European societies. ${ }^{60}$

Another major contributor to the globalisation of the peasant problems of Eastern Europe was Doreen Warriner (1904-72). ${ }^{61}$ Warriner was an Oxford trained British academic who wrote extensively on rural economic and social issues initially in Eastern Europe, and then, after the Second World War, in other parts of the world. Warriner gained her PhD in 1931 from Oxford and became assistant lecturer in political economy at University College London. In 1935 she received a Rockefeller Travelling Fellowship, which she used to travel through many regions of Eastern Europe, collecting materials for her book Economics of Peasant Farming (1939). In Romania she also met with the Bucharest sociologists through the statistician Sabin Manuilă. ${ }^{62}$ Warriner approached Eastern Europe's rural issues mainly from an economic perspective, criticising the great politicisation of this topic amongst local intellectuals. ${ }^{63}$ As the world descended into war Warriner became more directly involved in the new problems of Eastern Europe, playing an active role in rescuing Czechs and Jews persecuted by the Nazi regime after the Munich agreement (1938) and also working for the United Nations Relief and Rehabilitation Administration (UNRRA) in the immediate aftermath of war (1944-6). ${ }^{64}$ After her return to academia Warriner's research took a different direction, both conceptually and geographically. The closing off of Eastern Europe after the communist takeovers in 1948 meant that she pursued her interest in rural issues outside of Europe, first in the Middle East and then in other parts of the world, including India and Africa. ${ }^{65}$ Conceptually her work fell under the new field of development economics, a term that included many of the topics she had already approached in

\footnotetext{
57 James T. Shotwell, A Balkan Mission (New York: Columbia University Press, 1949), 82-103.

58 David Mitrany, Marx against the Peasant: A Study in Social Dogmatism (London: Weidenfeld \& Nicolson, 1951).

59 Anderson, 'Mitrany'.

60 Mitrany, Marx against the Peasant, XI-XII.

${ }_{61}$ Ann K. S. Lambton, 'Doreen Warriner, 1904-1972', The Slavonic and East European Review, 51, 123 (1973), 292-3.

62 Doreen Warriner, Economics of Peasant Farming (London: Oxford University Press, 1939), X.

${ }^{63}$ Doreen Warriner, 'Urban Thinkers and Peasant Policy in Yugoslavia, 1918-59', The Slavonic and East European Review, 38, 90 (1959).

64 Ann K. S. Lambton, 'Doreen Warriner, 1904-1972'.

65 Doreen Warriner, Land Reform and Development in the Middle East. A Study of Egypt, Syria and Iraq (London: Royal Institute of International Affairs, 1957); Doreen Warriner, Land Reform in Principle and Practice (Oxford: Clarendon Press, 1969).
} 
relation to Eastern Europe: land reforms, overpopulation, food and farming. Warriner's work therefore contributed directly to the global dimension of Eastern European rural issues. In an article from 1953 she noted that 'the study of the East European economy has now acquired an interest going beyond the study of the region itself; its outstanding features are seen to be characteristic of large regions in Asia and the Middle East' ${ }^{66}$ Her conclusion that 'Eastern Europe has thus come to be regarded as a prototype for the study of backward areas in general' highlighted the way in which the new paradigm of development, whose main roots were in the interwar period, had suddenly placed what appeared to be local affairs in a European periphery in a much wider context. ${ }^{67}$

The American scholar Philip Mosely (1905-72) represented another connection between Eastern and Western rural studies. Mosely came into close contact with the work of the Bucharest sociologists and contributed to publicising their work in the Western academic press. His work and career path also indicated the rising interest in the peasantry and, in his case, the rise of area studies in the Cold War era.

Mosely completed his doctorate at Harvard with a thesis on Russian social history, for which he had travelled to the Soviet Union between 1930 and $1932 .{ }^{68}$ Shortly afterwards Mosely received a Rockefeller Fellowship to travel to several countries in Eastern Europe, including Romania, to study the 'evolution of the peasant economy' in the region. In Romania his contact was the Bucharest sociologist Henri H. Stahl, with whom he shared an interest in the social history of rural communities. ${ }^{69}$ Between 1935 and 1936 Mosely travelled around other parts of the region, undertaking research in Albania, Serbia, Macedonia, Croatia, Bosnia and Slovenia. On his return to Romania he was invited to participate to the School's expedition to the village of Șanț in Northern Transylvania. As a result of this work he published an article in the journal Romanian Sociology (Sociologie românească) about a villager who had migrated to the United States for work and subsequently returned to his home country. ${ }^{70}$

After his return to the United States, where he took up a teaching position at Cornell University, he maintained a close connection with the Bucharest sociologists, publishing several articles on their work for the English-speaking academic community. ${ }^{71}$ Mosely praised not only the research initiatives of the School but also the application of social science to the transformation of the peasantry through the programme of "cultural work'. ${ }^{72}$

During and after the Second World War Mosely followed a career path similar to Mitrany's and Warriner's, combining his research with work for various US government departments and institutes where his knowledge and direct experience of Soviet society was put to practical use. He therefore became best known for his contribution to the establishment and advancement of Russian and Soviet Studies in the United States, although his interest in rural issues did not disappear. ${ }^{73}$ Like Warriner and Mitrany, Mosely emphasised the growing importance of rural issues to the interwar period, noting that 'one of the most significant developments in European life and thought today [was] the rediscovery of the peasantry. ${ }^{74}$

\footnotetext{
66 'Some Controversial Issues in the History of Agrarian Europe', The Slavonic and East European Review, 32,78 (1953), 1968.

67 Ibid., 169.

68 Alexander Dalin, 'Philip E. Mosely, 1905-1972', The Russian Review, 31, 2 (1972), 209-11.

69 Henri H. Stahl, Amintiri și gânduri (Bucharest: Ed. Minerva, 1981), 353-4.

70 Philip Mosely, 'Lumea Psihologică a Unui “American” Din Șanț', Sociologie Românească, 7-9 (1936), 75-8.

71 Philip E. Mosely, 'The Sociological School of Dimitrie Gusti', The Sociological Review, XXVIII (1936), 149-65; Philip Mosely, 'A New Rumanian Journal of Rural Sociology', Rural Sociology, 2, 4 (1937).

72 Mosely, 'A New Rumanian Journal'.

73 David C. Engerman, 'The Cold War's Organization Man. How Philip Mosely Helped Soviet Studies Moderate American Policy', Humanities, 30, 5 (2009), http://www.neh.gov/humanities/2009/septemberoctober/feature/the-coldwar-organization-man (last visited 9 Aug. 2018).

74 Mosely, 'A New Rumanian Journal', 457.
} 
Although many other Western scholars travelled to Romania and had close contact with the Bucharest School of Sociology, Mitrany, Warriner and Mosely best represent the interest in rural issues during the interwar period and the globalisation of this topic in the post-war period. All three came to Eastern Europe and to Romania using established pathways of academic exchange: the Carnegie and Rockefeller Foundations. Whilst working in different academic fields, social history, economics and sociology, they all realised the importance of studying and understanding the rural world to processes of political, economic and social modernisation in the area. Also, they all used their newly acquired knowledge of these matters to develop new directions of study after the war: international relations, economic development and area studies. Finally, the fact that all of them came in contact with the Bucharest sociologists and their work also indicated the international recognition of the School in this period.

\section{Meeting Points: The International Stages}

Apart from the individual and institutional connections, another way to understand how discussions about the rural world became global is to look at the international stages upon which academic knowledge was presented. In this period there were many opportunities for scholars to present their work at international fairs, exhibitions and conferences. The participation of the Bucharest School in such events shows both how local matters gained global resonance and how personal connections facilitated institutional exchange and cooperation.

A defining feature of the Bucharest School of Sociology was its great talent for public engagement. Gusti was able to popularise his discipline and the method of field research, both at home and abroad, using a complex network of scholars, politicians and intellectual figures. Gusti's public roles gave him access to networks abroad as well. In the 1930s, and especially after Carol II came to power, Gusti became one of the main representatives of Romanian social science and reform abroad. In 1937 and then again in 1939 he was charged with the organisation of the Romanian pavilion at the Paris and New York World Fairs. ${ }^{75}$

This responsibility represented the peak of a longer interest and experience of collecting and exhibiting rural life pioneered by Gusti and his team of students since their earlier expeditions to the countryside. The School was in perfect synchronicity with the international exhibiting trends of the time, both through their aesthetics and their ideas. Gusti's involvement in the wider international arena helped connect the School's research and exhibitions to the agendas of international organisations who were actively supporting research and interstate cooperation on common issues of social hygiene, housing and nutrition. ${ }^{76}$ For example, Gusti had secured funding from the Rockefeller Foundation both for publications and for the doctoral studies of many of his collaborators. Similarly, placing the School's work under the auspices of the League of Nations and their special concern with social hygiene, their displays travelled from the University seminar rooms in Bucharest straight to several international exhibitions and world fairs, such as the Barcelona International Exhibition (1929), the International Hygiene Exhibition in Dresden (1930), the Paris World Fair (1937) and the New York World Fair (1939). ${ }^{77}$ These exhibitions were stages for universal encyclopaedic ambitions and for nationalist discourses, where states presented both their uniqueness and their universality. These two features gave further meaning to the sociological displays of Romanian villages, not only as symbols of the nation but also as part of new (global) ways of seeing the rural world in general.

\footnotetext{
75 Bădina and Neamțu, Dimitrie Gusti.

76 Iris Borowy, 'International Social Medicine between the Wars. Positioning a Volatile Concept', Hygienia Internationalis, 6, 2 (2007).

77 Laurențiu Vlad, Imagini ale identității naționale. România și Expozițiile Universale de la Paris, 1867-1937 (Iași: Ed. Institutul European, 2007); Raluca Mușat, 'Prototypes for Modern Living: Planning, Sociology and the Model Village in Interwar Romania', Social History, 39 (2014).
} 


\section{Exhibiting the Countryside}

Two examples illustrate the interplay between the local, national and international context and its effects. The Drăguș room was one of the earlier displays of objects collected by the sociological team during their trip to Transylvania in 1929. The objects, representing the interior of a traditional house, were displayed in one of the seminar rooms at the University of Bucharest. They were then exhibited at the Hygiene Exhibition in Dresden (1930). The Dresden exhibition reflected the rise of a global concern with health and hygiene in which the rural world played a significant part. $^{78}$ Debates and projects on public health had gained new social and local dimensions, with international organisations funding and supporting rural initiatives. ${ }^{79}$ The presence of the sociological and ethnographic artefacts from Drăguș at this major exhibition of public health and social hygiene signalled the shifting perspective on rural life in this era. Peasant living conditions were no longer matters of local interest alone and peasant objects were not only collectable artefacts. Instead, without losing these earlier connotations, vernacular ways of life were becoming matters of global interest on international agendas of development and world health.

Alongside these specialised exhibitions the LNHO organised several conferences on rural health and hygiene, culminating with a special pavilion on rural housing at the 1937 Paris World Fair. Sociologists were at the heart of the Romanian pavilions in Paris: Gusti had been appointed as the main coordinator, while Stahl was in charge of the Romanian section in the special Exhibition on Rural Housing at Porte Maillot sponsored by the LNHO. The exhibition invited specialists from many countries to present the current state of the countryside in their homelands and to discuss plans for the improvement of rural living conditions and of housing more specifically. ${ }^{80}$ Once again, this integrated the research on the Romanian countryside within an international concern with rural development.

\section{The International Congress of Sociology}

Another stage for the promotion of Romanian sociology was the planned International Congress of Sociology meant to take place in Bucharest in $1939 .{ }^{81}$ Although it was cancelled because of the imminent start of the Second World War, this event indicated both the prominence of Romanian sociology on an international stage and their ability to focus international research agendas on the problems of the rural world.

The Congress was the outcome of a string of international connections that are interesting and revealing in themselves. The main facilitator of the Bucharest Congress was the Romanian Gheorghe Vlădescu-Racoasă, who had been Gusti's first assistant at the University of Bucharest and had later pursued a diplomatic career, acting as Romania representative at the International Labour Organisation (ILO) in Geneva between 1929 and 1940. This position at the ILO, then headed by the French sociologist Albert Thomas, allowed Racoasă to became actively involved in the International Congress of Sociology, which was relaunched in the 1927 under the leadership of Gaston Richard. Racoasă used this connection to publicise the works of the Bucharest School of Sociology at the congresses of 1933 (Geneva), 1935 (Bruxelles) and in 1937 (Paris). At the last one, which he, Gusti and Stahl also attended, the members of the association unanimously decided that the following congress be held in Bucharest in 1939.

The central theme of the Bucharest Congress was to be 'The Village and the City'. This was to be examined through a comprehensive set of subcategories that mirrored Gusti's holistic

\footnotetext{
78 Murard, 'Designs within Disorder'.

79 Ibid.

80 Borowy, Coming to Terms with World Health, 344-6.

${ }^{81}$ Zoltán Rostás, 'L'histoire d'un congrès qui n'a pas eu lieu. Le XIVème Congrès International de Sociologie (Bucarest, 1939)', Les Etudes Sociales, 153-4 (2011).
} 
approach, including discussions about 'social units', methods of study, issues specific to the rural and urban and their relationship, the importance of social institutes and the teaching of sociology. The theme indicated the worldwide concern with the rural as well as the prominence of Romanian rural sociology in this global context. As Stahl noted, the choice of Bucharest as the location for the International Congress 'was not made by chance'. 'We had five regional Social Institutes' he continued 'a Village Museum . . . and five research teams working in the villages of Drăguș, Nerej, Șanț, Runcu and Clopotiva'. 82 As noted in an article published in Sociologie românească in 1938, the relationship between the city and the country was a theme that 'interested equally both American and European sociologists and allowed the Bucharest School to exhibit their own work'. ${ }^{83}$ Moreover, the published papers submitted for the Congress reflected a wide geographic spread and a range of different topics related to the rural world. The volumes on the village and the city, for example, included studies of Balkan and East European rural areas (Poland, Yugoslavia, Bulgaria, Czechoslovakia, Greece, Turkey), West European ones (France, Germany, Netherlands, Italy, Scotland) and South American ones (Brazil).

The imminence of the Congress had important repercussions in Romania, where many unfinished projects were hastened to completion. The event mobilised all available forces towards the writing up of existing materials and the collection of others. The role of these publications was to present the School and its projects to an international scholarly public. Two of the monographs, Nerej and Drăguș, were published in French and English, respectively, aiming almost exclusively at a foreign readership. ${ }^{84}$ Apart from studies, the Congress was meant to include trips where foreign scholars could observe the work of Romanian researchers in the countryside. This novel addition added to the complex preparations for the Congress in the host country.

The aborted 1939 Congress of Sociology also showed the importance of international networks in galvanising attention around a specific topic. Gaining international prestige was a process that relied not only on the production of valuable work, but also on the ability to gain access and to make the right connections that would allow this work to be staged or even finalised for a wider audience. This meant access not only to academic but also to other types of public networks of knowledge such as the ILO and the LNHO. Gusti and Vlădescu-Racoasă's careers highlight that fact that sociologists were often more than just sociologists; instead they were also public figures that swiftly moved between and connected the academic and the political arenas. The Congress can also be taken as proof of the success Romanian sociologists had in bringing the rural world to the forefront of international sociology, attracting scholars from all over the world around this matter of global concern.

The war marked a sharp break in international intellectual cooperation. Many of the scholars mentioned in this article placed their work in the service of their own states (Golopenția, Mitrany, Mosely) or in that of international organisations (Warriner). After the war, however, new opportunities for the retying of relations and for new collaboration seemed possible. This was certainly evident in the discussions between Golopenția and his Western colleagues in the mid 1940s. However, even before 1948 the mood regarding international cooperation had changed. In a letter to Golopenția Mosley commented that 'Gusti's projects for a great international institute [for the Social Sciences] does not fit well with the American psychology, which is suspicious of centralisation and is fond of autonomy and of partial initiatives in what concerns the social sciences'. ${ }^{85}$

\footnotetext{
82 Stahl, Amintiri, 368-70.

83 'Congresul Internațional de Sociologie de la București', Sociologie Românească, III, 07-09 (1938), 410.

${ }^{84}$ Henri H. Stahl, Nerej, un village d’une région archaïque, vol. 1 (Institut de Sciences Sociales Roumaines, 1939); Traian Herseni, ed., Drăguş, un sat din Țara Oltului (Făgăraş), vol. 1-6 (1944).

85 Philip Mosely, 'Scrisoare Philip Mosely - Anton Golopenția (26.9.1946)', in Golopenția, Ultima carte, 372.
} 
The advent of the Cold War meant that all individual links between scholars in East and West were suppressed. A mood of suspicion and widespread retribution descended over academic work, mainly in the East but also in the West. Later on, from the late 1950s to the 1970s, as academic relations were retied at an institutional level, some of the topics debated before the war were resurrected and some of the old relations were re-established. However, by this time, the politics directed at the rural world in Eastern Europe had changed considerably under communist rule, whilst the end of European colonial empires expanded the interest in rural development beyond Europe to the new 'Third World'.

\section{Conclusion}

The international networks of knowledge set up in the interwar period played an important role in creating global ways of conceptualising and intervening in the rural world in the post-war decade. Eastern Europe played a crucial role in this process, as an international hub of rural research. Firstly, this was a main centre where knowledge about the rural world was produced. Secondly, as this article shows, this 'local knowledge' was translated and connected to international themes about the rural world. Thirdly, this knowledge also fed into the works of scholars coming from Western Europe and the United States, whose works constructed a regional and comparative vision of the region and its rural problems that later fed into a vision of a global countryside that became prominent after the war. Finally, institutional connections and international stages also allowed research from and on Eastern Europe to gain a global dimension.

The approach used in this article reveals how scholars from East and West used international networks and cooperation differently. For the Bucharest School of Sociology, on the one hand, national affirmation was primordial and most members of the School used their opportunities for international formation to advance their discipline in a national way. The name of the School's main journal, Romanian Sociology, reflected this most clearly: the scholars were working towards creating a national sociology. On the other hand, Western scholars travelling to the region and studying the peasantry used the access provided by the local scholars as a way to produce their own vision of the East European countryside. This in turn became an opportunity to expand their discipline and to create new areas of study both before and after the war. The cooperation and dialogue between the two 'sides' therefore resulted in an equitable exchange of access and knowledge: the locals offered access to their fieldwork, while the visitors offered access and connections to international publications, stages and institutions. Thus, contributing to a global vision of the peasantry was not a matter of simply advancing a subject matter but of gaining academic recognition within various academic and even political environments.

The stages and opportunities for Romanian sociology to present their ideas about the rural world operated in multiple ways. International exhibitions, for example, connected local issues to global debates, infusing them with new meaning, while the 1939 Congress of Sociology in Bucharest indicated that Eastern Europe had become a centre of research on rural issues. In turn, the knowledge produced in and about the region fed into new ways of conceptualising and ultimately governing the rural world in the post-war period. 